\title{
Note
}

\section{REFORMING THE LEGISLATION ON THE INTERNATIONAL COMMERCIAL ARBITRATION OF UKRAINE: REALITIES OR MYTHS}

\author{
Yuriy Prytyka, Vyacheslav Komarov and Serhij Kravtsov
}

Summary: 1. Introduction. - 2. The Possibility of the Consideration of Investment Disputes by International Commercial Arbitration. - 3. The Correlation of the 'Place of Dispute' ICA with the Theory of Delocalisation. -4 . The Procedure for Establishing Institutional Arbitration Courts. - 5. Changing the Procedure for Appointing Arbitrators. - 6. Conclusions.

To cite this article: Yu Prytyka, V Komarov, S Kravtsov, 'Reforming the Legislation on the International Commercial Arbitration of Ukraine: Realities or Myths' 2021 3(11) Access to Justice in Eastern Europe 117-128. DOI: 10.33327/AJEE-18-4.3-n000074

To link to this article: https://doi.org/10.33327/AJEE-18-4.3-n000074

Submitted on 14 Jun 2021 / Revised 20 Jun 2021 / Approved 26 Jul 2021 / Published online: 02 Aug 2021 View data

Submit your article to Access to Justice in Eastern Europe

\section{CONFLICTS OF INTEREST}

The authors declare no conflict of interest of relevance to this topic. Prof. Prytyka serves as a Member of the Advisory Board of the journal; thus, he was not involved in decision making, and this note underwent the full process of peer review and editing. Although two authors serve in AJEE, which may cause a potential conflict or the perception of bias, the final decisions for the publication of this note was handled by other editors, including choice of peer reviewers.

\section{DISCLAIMER}

The authors declare that they were not involved in any state body's activities related to the discussed Draft law. Prof. Prytyka serves as a Member of the International Commercial Arbitration Court in Ukraine but does not represent any views of this body in this research, nor is he bound by that body in his opinion.

\section{ACKNOWLEDGEMENTS}

The authors would like to express their gratitude to the reviewers and editors of the journal and to the English editor, Sarah White. 


\title{
REFORMING THE LEGISLATION ON THE INTERNATIONAL COMMERCIAL ARBITRATION OF UKRAINE: REALITIES OR MYTHS
}

\author{
Prytyka Yuriy \\ Dr. Sc (Law), Head of Department of Civil Procedure, Law School of the \\ Taras Shevchenko National University of Kyiv, Ukraine \\ prytykau@knu.ua \\ https://orcid.org/0000-0001-5992-1144
}

\section{Komarov Vyacheslav}

Professor, Member of the National Academy of Legal Sciences of Ukraine, Yaroslav Mudryi National Law University, Ukraine

v.v.komarov@nlu.edu.ua

https://orcid.org/0000-0002-4378-9772

\section{Kravtsov Serhij}

PhD (Law), Associate Professor, Department of Civil Procedure,

Yaroslav the Wise National Law University

s.o.kravtsov@nlu.edu.ua

https://orcid.org/0000-0002-8270-193X

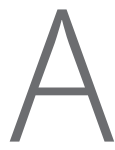

bstract International commercial arbitration (ICA) is an alternative way to resolve foreign economic disputes. Initially, arbitration itself was seen as a neutral court in which the parties to the dispute were independent of national courts. Arbitration agreements and decisions must be recognised by national courts without any complications or review procedures.

Although granting commercial parties some independence to agree that their dispute will be considered by independent arbitrators is a key principle in ICA, the struggle for supremacy between national laws and national courts on the one hand and the autonomy of the parties and the independence of the international arbitration system on the other continue. Over the years, national laws have sought to control, regulate, interfere with, or support ICA in various ways. To counter attempts to 'localise' ICA and promote equality in this area, private, professional institutions and international and intergovernmental organisations have developed a significant body of law designed to ensure self-government and dispute settlement procedures in ICA.

Nevertheless, international commercial arbitration cannot exist independently of national jurisdictions. Examining the activities of ICA, it can be seen that the importance and impact of national arbitration laws and national judicial supervision are significantly reduced, but the lex fori still plays an important role in arbitration. Thus, the reform of the normative regulation of international arbitration also affected Ukraine. The article analyses the radical changes proposed by the legislator regarding the procedure for establishing institutional arbitrations, expanding the arbitrability of disputes.

Keywords: international commercial arbitration, delocalisation, arbitration agreement 


\section{INTRODUCTION}

International commercial arbitration (ICA) occupies an important place among alternative methods of dispute resolution in the field of international trade. Therefore, the improvement of its legal regulation in light of current trends in the development of this institution is permanent in all countries. In many countries, arbitration law reflects the nature of arbitration as an alternative means of resolving disputes arising in the field of economic circulation, which is based on contract and excludes the jurisdiction of state courts to consider a particular case. The contractual nature of arbitration means that its formation is the prerogative of the parties. The establishment or election of arbitration is carried out by the parties between whom there is a dispute over the right. The legislation of different states, as a rule, provides for the possibility of international commercial arbitration of civil cases between national and foreign legal entities and, in some cases, the possibility of arbitration of civil cases in disputes between foreign entities of rights.

The harmonisation of national legislation on international commercial arbitration in Ukraine is a rather complex process, as the attractiveness of using this alternative method of dispute resolution is growing, and legislative consolidation cannot always keep pace with modern challenges. The legislation of Ukraine governing international commercial arbitration includes two main sources: the Law of Ukraine 'On International Commercial Arbitration $^{1}$ of 1994 and the Code of Civil Procedure of Ukraine, ${ }^{2}$ which contain tools for monitoring and facilitating international commercial arbitration. In general, the arbitration legislation of Ukraine meets international standards, in particular, those provided for in the UNCITRAL Model Law on International Commercial Arbitration.

An important recent reform of the arbitration legislation of Ukraine was the adoption of amendments to the CPC of Ukraine of 2017, which introduced separate chapters on procedural issues of the recognition and enforcement of ICA decisions and the procedure for revoking ICA decisions. Following these changes, the case-law has become more pro-arbitration.

In 2021, the Ministry of Justice of Ukraine developed a new Draft Law aimed at improving the regulation of ICA. Thus, the Draft Law of Ukraine 'On Amendments to Certain Legislative Acts of Ukraine Concerning the Improvement of Arbitration' was registered in the Verkhovna Rada of Ukraine (No. 5347 of 8 April 2021). ${ }^{3}$ According to the analysis of the Draft Law, it proposes to amend the legislation of Ukraine in the following areas: 1) expanding the arbitrability of disputes that can be referred to international commercial arbitration through: a) civil contractual relations in the areas of property privatisation and public procurement; b) corporate relations; c) disputes involving a non-resident related to investments made by a foreign investor in Ukraine or a Ukrainian investor abroad; 2) the possibility of establishing permanent arbitration institutions in Ukraine, the founders of which are proposed to determine non-profit organisations registered in accordance with the legislation of Ukraine or branches and representative offices of organisations registered in accordance with foreign law and that are founders of arbitration institutions abroad; 3) establishing the procedure for resolving issues related to determining the composition of the arbitration by the state court.

1 Law of Ukraine ‘On International Commercial Arbitration' of 24 February 1994 No 4002-XII (updated on 15 December 2017) <http://zakon5.rada. gov.ua/laws/show/4002-12/ parao171\#o171> accessed 16 July 2021.

2 Law of Ukraine 'Civil Procedure Code of Ukraine' of 18 March 2004 No 1618-IV (updated on 4 November 2018) <http://zakon.rada.gov.ua/laws/show/1618-15> accessed 16 July 2021.

3 Draft Law of Ukraine 'On Amendments to Certain Legislative Acts of Ukraine Concerning the Improvement of Arbitration Activities’ of 08 April 2021 No 5347 <http://w1.c1.rada.gov.ua/pls/zweb2/ webproc4_1?pf3511=71614> accessed 25 July 2021. 
The proposed changes have caused considerable discussion among legal practitioners and scholars, who have been quite critical of some provisions of the Draft Law. While carrying out own analysis of the mentioned offers, it is necessary to focus on the following problematic moments.

\section{THE POSSIBILITY OF THE CONSIDERATION OF INVESTMENT DISPUTES BY INTERNATIONAL COMMERCIAL ARBITRATION}

According to the Draft Law 'On Amendments to Certain Legislative Acts of Ukraine on Improving Arbitration' of 8 April 2021, 'disputes involving a non-resident related to investments by a foreign investor in Ukraine or a Ukrainian investor abroad' are to be referred to the competence of ICA in Ukraine. The proposals set out in the Draft Law on the inclusion of investment disputes with the participation of a non-resident to the authority of ICA are of a somewhat controversial nature and should be considered in a certain set of applications of international and national legislation.

Investment arbitration is a procedure for settling disputes between foreign investors and host countries. The possibility for a foreign investor to file a lawsuit against the host state is a guarantee for the foreign investor that in resolving the dispute, they will be able to obtain consideration of such dispute by independent and qualified arbitrators, and such arbitral awards will be effectively enforced. This allows a foreign investor to bypass national jurisdictions, which may be perceived as biased and not endowed with sufficient qualifications to deal with such disputes as provided for in international treaties.

For a foreign investor to apply to investment arbitration, the host state must give consent to it. Consent to investment arbitration is most often given by host countries in international investment agreements, including bilateral investment agreements, as well as free trade agreements and multilateral agreements. For example, in Part 3 (a) of Art. 26 of the Energy Charter Treaty, ratified on 6 February 1998, it is stated that subject to subparagraphs (b) and (c) only that each Contracting Party hereby gives its unconditional consent to the transfer of the dispute to international arbitration or conciliation in accordance with the provisions of this article.

To a lesser extent, such consent to investment arbitration may be enshrined in investment agreements concluded directly between the state and a foreign investor, or it may be contained in the domestic legislation of the host country, such as legislation governing mining or investment. The United Nations Conference on Trade and Development (UNCTAD) maintains a list of such agreements that provide for the consent of the host country to investment arbitration, which should be consulted from the outset of any potential dispute to determine whether investment arbitration can be envisaged.

As a rule, the consent is based on the rules of citizenship of the individual investor or the location of the legal entity, which provides some flexibility in terms of international agreements, according to which arbitration of investment disputes may be initiated.

For an investor to be able to choose the consideration of their dispute in international commercial arbitration, they must have appropriate material protection. Material protection provided to foreign investors depends on the international investment agreement on the basis of which their claims are made. They differ from the protection provided by the domestic law of the receiving state.

For most investment arbitration agreements, a six-month period is typically provided for, during which the investor and the host country are invited to enter into negotiations to find a 
mutually acceptable solution. The starting point for the conciliation period is usually a notice of intent to sue the host state against the arbitral tribunal. In the event of an unresolved dispute during the conciliation period, as is usually the case (many states prefer to wait and see if a foreign investor is willing to pay the high costs required for investment arbitration), the foreign investor must apply for arbitration in accordance with applicable arbitration rules.

The average term of arbitration in investment disputes is a little over three years. According to statistics from the International Center for the Settlement of Investment Disputes (ICSID), in 2015 , the length of arbitration proceedings was ' 39 months on average. The longest-running dispute in the history of ICVIS lasted for nineteen years, but this was an exceptional case.

Thus, the proposals set out in the Draft Law may completely disregard the advantages of ICA in terms of speed of dispute resolution in contrast to national jurisdictions. In addition, the inconsistency of national legislation and international agreements on the possibility of consideration of investment disputes by ICA will be an indisputable ground for refusing to recognise and grant permission to enforce the decision of ICA and revoke such arbitral decisions in accordance with Art. 478 and Art. 459 of the CPC of Ukraine.

In addition, these changes actually duplicate Part 5 of Art. 1 of the Russian Federation Law 'On International Commercial Arbitration', in accordance with which in cases provided for by international treaties of the Russian Federation and federal law, disputes involving a foreign investor in connection with foreign investment in the territory of the Russian Federation or Russian investments abroad not covered by this article may be transferred to international commercial arbitration.

In our opinion, the proposal to submit investment disputes that arise between a foreign investor and the state to ordinary international commercial arbitration is not realistic enough because bilateral interstate investment agreements provide a special procedure for resolving investment disputes and embody established practice. As an example, we can cite Art. 9 of the Agreement on Promotion and Mutual Protection of Investments between Ukraine and Qatar in 2018, which provides for the following ways to resolve investment disputes: a) negotiations, b) appeal to the competent state court of the country of investment; c) settlement of a dispute by the International Center for the Settlement of Investment Disputes, established in accordance with the 1965 Convention on the Settlement of Investment Disputes between States and Foreign Persons; d) the establishment of an ad hoc Arbitration Tribunal to settle the dispute in accordance with the Arbitration Rules of the United Nations Commission on International Trade Law (UNCITRAL). ${ }^{4}$

The idea of the Draft Law to improve the investment climate in Ukraine by transferring investment disputes to national arbitrations has been criticised in Ukrainian periodicals. V. Nahnybida notes that the idea of creating an arbitration attractive to investors was also worked out by 'bringing here (to Ukraine) arbitrators, foreign judges' and creating an arbitration 'that would have great reputation, would be reliable, would work on a par with Stockholm and London'. Although such initiatives and the format of their implementation have been criticised (often fairly) in professional circles, until recently, the fact that the current government realised the direct connection between the institution of arbitration and investment attractiveness and investor confidence in the state gave hope. In addition, such statements indicate the government's intention to offer Western partners and Europeanlevel businesses a platform for resolving international commercial and investment disputes by highly professional, experienced, and reputable arbitrators. And this is also the right

$4 \quad$ Agreement on Promotion and Mutual Protection of Investments between the Government of Ukraine and the Government of the State of Qatar <https://zakon.rada.gov.ua/laws/show/634_004-18\#Text> accessed 25 July 2021. 
approach. After all, the legal nature and specifics of these disputes really require quality administration of their resolution and professional arbitrators, and since the latter decisions are executed mainly in foreign jurisdictions, the confidence of foreign investors and the country's image in the eyes of foreign partners and companies really depend on the quality of such decisions. ${ }^{5}$

Therefore, in most cases, investment disputes are considered in a special manner, and national ICAs perform the functions of the competent authorities to assist in the organisation of arbitration under the UNCITRAL regulations. It is unlikely that a foreign investor, in the event of a dispute with a state, will choose that state as the place of arbitration with an appropriate mechanism for reviewing the arbitral decision by the state courts of that state.

\section{THE CORRELATION OF THE'PLACE OF DISPUTE' ICA WITH THE THEORY OF DELOCALISATION}

It should be noted that along with the unification of the ICA, the issues of its delocalisation, which is understood as the separation of arbitration from the national legislation of the state of the arbitration, including its substantive and procedural rules, are currently being actively discussed.

Most scholars and practitioners ${ }^{6}$ traditionally hold the view that the activities of an international arbitral tribunal are carried out only within the framework of national law. In doing so, they draw attention to the following: a) international commercial arbitration is a national legal institution provided for by national law; b) even special rules related to arbitration between different countries and established by international conventions have legal force only to the extent to which the force within each of the national legal systems is recognised by those conventions; c) the legal force of an international arbitral decision and the possibility of its enforcement in a particular state depend on whether the relevant procedure established in that state was followed during its issuance.

Representatives of the theory of delocalisation consider international arbitration separate from national legal systems and their norms and principles and believe that the sphere of international commercial relations can be better served by a system of more or less codified universal norms developed on the basis of international experience.

Thus, according to D.K. Moss, unlike a state judge who is obliged to act in accordance with the rules of conflict law of the state on which behalf they administer justice, an arbitrator is not bound by such rules. ${ }^{7}$ Many supporters of the delocalisation theory assume that the independence of the law of the place of arbitration or any other national law emphasises the principle of autonomy of the parties as the leading idea relevant to the delocalisation process.

The theory of delocalisation is related to approaches that consider international commercial arbitration exclusively as a contractual phenomenon and is based on the following arguments: separation from any national rules, both procedural and private international law, but compliance with mandatory rules of public order; separation from the norms of private international law and public order of the state, but compliance with procedural norms; separation from any norms of the national legal system.

$5 \quad$ V Nahnybida, 'The Crisis of Trust' (2021) 4 (129) Court Bulletin.

6 D Janićijević, 'Delocalization in International Commercial Arbitration' (2005) 3 (1) Law and Politics 63.

7 DK Moss, Autonomy of Will in the Practice of International Commercial Arbitration (Moscow 1996$) 11$. 
Despite the significant differences between these approaches, neither excludes the possibility of international treaty unification of procedural rules. The analysis of the traditional approach shows that its supporters recognise the possibility of international treaty unification, but such unification should take place only to the extent that it is recognised by the states, which are parties to the relevant international treaties. Supporters of the theory of delocalisation recognise the international unification of the legal regulation of the dispute resolution process by an international arbitral tribunal as a necessary condition for the existence of the ICA as such. At the same time, as for the method of unification, they insist on the application of the substantive law and not the conflict method, as the latter actually leads to the application of procedural law of a particular country. However, this creates problems related to the implementation of the arbitration award, as well as to the unification process itself. ${ }^{8}$

One of the most prominent supporters of delocalisation theory, Ian Paulson, argued that ICA should not be limited by procedural law to the place of arbitration, as arbitration powers are not provided by law to the place of arbitration and should not be subject to judicial review. According to this point of view, the parties may enter into a foreign trade contract in which the arbitration proceedings will be deprived of the intervention of state courts for their own interest. Such arbitration in the theory of law enforcement is called 'flexible' because it does not depend on the domestic law of the country where the arbitration is taking place. Thus, it can be seen that the theory of delocalisation is very attractive for both arbitrators and sides of arbitration review, as quite often the place of arbitration is chosen for reasons of convenience or neutrality, ignoring any coercion by the state and making it impossible for the state court to decide about the non-arbitrability of the dispute. Thus, the theory of delocalisation ultimately improves the liberalisation of the choice of procedural law in international arbitration. ${ }^{9}$

In modern conditions, it is noticeable that the processes of delocalisation of the ICA are manifested in the formation of universal arbitration rules, which are designed to be self-sufficient to prevent any interference of state courts. However, negative views on delocalised arbitration are based on the premise that arbitration should always have a 'place' and be implemented in national law. As F. Mann noted, every arbitration is a national arbitration according to the system of national law. Each arbitration must be subject to the law of a state. Every system of law or state power derives from a system of national law, which may be called the law of arbitri. ${ }^{10}$ Yet, over time, some scholars, as well as practitioners, lay the foundations of the theory and practice of delocalised arbitration, which is manifested in non-interference by the state. The function of state courts should be aimed only at controlling the arbitration process.

Delocalisation of international commercial arbitration is characterised by its universal nature. It contributes to the improvement of new international trends in the development of arbitration, in particular, in the form of implementation of international commercial contracts, which are mainly related to public authorities. As an example, the UNCITRAL Model Law can be seen as a right for the delocalisation procedure, as it gives greater freedom to seek any other alternatives for resolving any dispute between the parties in ICA proceedings. ${ }^{11}$

$8 \quad$ K Piątkowska, "The Concept of "Denationalization" (or the Equivalent "Delocalization") in the Context of the US Federal Court Decision in Chromalloy Aeroservices Inc v Arab Republic of Egypt 939 F Supp 907 (DDC 1996) and the Amsterdam Court of Appeal Decision in Yukos Capital SARL v OAO Rosneft' (Wrocław 2009).

9 J Paulsson, The Idea of Arbitration (Oxford University Press 2013).

10 FA Mann, 'Lex Facit Arbitrum' in P Sanders (ed), International Arbitration: Liber Amicorum for Martin Domke (The Hague: Martinus Nijhoff 1967) 157-183.

11 United Nations Commission on International Trade Law, UNCITRAL Model Law on International Commercial Arbitration, adopted by UNCITRAL on 21 June 1985 in the wording of 2006 (United Nations Publication 2008) 40. 
By becoming more independent of national legal systems, arbitration acquires new qualities. Conventionally speaking, in resolving a dispute, arbitration does not 'join' any legislation and primarily supports the interests of international trade. Thus, delocalised arbitration can be considered as a form of arbitration of foreign economic disputes, which is independent of any national legal system.

The main feature of delocalised arbitration is that it is based on the agreement of the parties. The second characteristic feature of delocalised arbitration is that its procedure should not violate the basic rules of international arbitration, which are recognised in each country where arbitration is practiced. These norms include the concepts of natural justice and other minimum norms of transnational legislation, which are reflected in the main international conventions.

If the arbitration is not based on these standards, it is impossible to recognise the law of the place of arbitration or the place of execution of the arbitral award. Similarly, delocalised arbitration does not give the arbitrator the right to act as a mediator. ${ }^{12}$ Finally, delocalised arbitration allows the application of a law provided for in a treaty or the law of another state, while the question of the arbitration procedure is determined at the level of autonomy of the parties. Regarding such rules, it can be said that delocalisation does not provide an opportunity to consider the case in the state where the arbitration is located. Although the state may not always exercise its powers in relation to the delocalised arbitration where it is located, it may, in accordance with national law, refuse to hear a case in international commercial arbitration.

In addition to being critical, two principles can be formulated for delocalised arbitration. The first is that arbitration cannot contradict the public order of the state. The second is that the limits of delocalisation of the ICA are determined by the autonomy of the parties and the harmonisation of their interests beyond the regulation of national law.

The advantages of delocalised arbitration are that it guarantees neutrality in litigation and limits the role of national courts in litigation, offers government agencies and institutions the ability to resolve disputes without interfering with foreign law, allows parties to choose the law that best suits them in accordance with the specifics of the agreement and their interests. ${ }^{13}$

Thus, delocalised arbitration in the aspect of international legal reality acts as the main factor in the realisation of the right to protection of the parties in a foreign economic dispute. To assume that all international arbitration is based on certain national legal systems is to ignore the existing reality. Therefore, the proposals set out in the Draft Law contradict the international doctrine of delocalisation of international commercial arbitration.

\section{THE PROCEDURE FOR ESTABLISHING INSTITUTIONAL ARBITRATION COURTS}

The Draft Law stipulates that Permanent arbitration institutions may be established and operate under:

a non-profit organization registered in accordance with the legislation of Ukraine and entered in the Register of non-profit institutions and organizations, the term of which from the moment of state registration to the decision to establish a permanent arbitration institution is more than ten years;

12 P Fouchard, 'Lautonomie de l'arbitrage commercial international' (1965) 1 Revue de l'arbitrage 99-120.

13 SO Kravtsov, International Commercial Arbitration and National Courts (Pravo 2014) 232. 
a branch or representative office of an organization registered in accordance with the legislation of a foreign state on the territory of Ukraine, provided that such organization is the founder of an arbitration institution abroad, the term of which is more than five years.

These proposals were not accepted by experts in the field of international commercial arbitration. Taking into account the existing mechanism in Ukraine for resolving international commercial disputes by arbitration, it is difficult to find certain preconditions that would support the proposed government initiative to establish a regulatory mechanism for the establishment and operation of permanent arbitrations under public organisations. After all, taking into account that the ICAC at the Ukrainian Chamber of Commerce and Industry currently performs the function of resolving such disputes, statistics for the last 10 years convincingly show that quantitative and qualitative indicators of decisions made, as well as the annual number of cases accepted for consideration, are far from those needed to ensure the necessity to introduce (revise) a mechanism for resolving such disputes by creating 'other permanent arbitrations'. There is no such practice in foreign countries, where for many decades there are leading national arbitration centres for dispute resolution, which are the focus and leading institutions for resolving international commercial disputes and within which best practices are developed, around which the arbitration community and leading experts are formed. Dispute resolution, which embodies and implements the highest standards of arbitration, has a high authority and enjoys the trust of business (ICC, LCIA, AAA, SCC, VIAC, SIAC, CIETAC, and others). In most countries, as mentioned above, such institutions are established and operate at the Chambers of Commerce (International Chamber of Commerce, Stockholm Chamber of Commerce, Milan Chamber of Commerce, China Chamber of International Trade, Chamber of Commerce of Poland, Romania, Swiss Chamber of Commerce Association, etc.). ${ }^{14}$

In addition, O. Podtserkovnyi claims that Draft Law No. 5347 gives the right to create international arbitrations an indefinite number of non-profit organisations deprived of such trust. At the same time, in accordance with sub-clause 133.4.1 of clause 133.4 of Art. 133 of the Tax Code of Ukraine, a non-profit organisation is a legal entity that is on the general taxation system but is not a payer of income tax. That is, it is a legal entity that does not pay personal income tax. According to the Tax Code of Ukraine, the status of non-profit organisations are obtained by: budgetary institutions; public associations, political parties, creative unions, religious organisations, charitable organisations, pension funds; unions and other associations of legal entities; housing construction cooperatives, country (country construction), horticultural and garage (garage construction) cooperatives (societies); association of co-owners of apartment buildings, associations of homeowners; trade unions, their associations, and trade union organisations, as well as employers' organisations and their associations; agricultural service cooperatives and their cooperative associations; other legal entities whose activities meet the requirements of para. 133.4 of Art. 133 of the Tax Code of Ukraine. As can be seen from the above list, the right to establish international arbitrations will be granted to thousands of legal entities in Ukraine. And the condition of 10 years from the moment of registration will serve here as a very formal restriction. This threatens to destroy the credibility of the institution of ICA, as it will open the way to abuse of jurisdiction in international arbitration, the creation of arbitration under an 'economically strong entity', a monopolist, and not in the interests of the legal system and arbitration. ${ }^{15}$

$14 \quad$ V Kovalskyi, 'New Initiatives for Improving the Legislation of Ukraine in the Field of International Arbitration: Pro Et Contra' (2 May 2021, Yurinkom Inter) <https://yurincom.com/legal_practice/ analitychna_yurysprudentsiia/novi-initsiatyvy-shchodo-vdoskonalennia-zakonodavstva-ukrainy-usferi-mizhnarodnoho-arbitrazhu-pro-et-contra/> accessed 25 July 2021.

15 O Podtserkovnyi, 'Reform and Content' <https://icac.org.ua/wp-content/uploads/StattyaPodtserkovnogo.pdf > accessed 25 July 2021. 
In our opinion, in making such a proposal, the authors of the Draft Law did not take into account the negative experience of the establishment and operation of domestic arbitration courts after the adoption of the Law of Ukraine 'On Arbitration Courts' in 2004, when 'pocket' arbitration courts began to be created. In particular, due to overly liberal requirements for the establishment and registration of arbitration courts. That is why the Cabinet of Ministers of Ukraine submitted to the Verkhovna Rada of Ukraine in 2020 a draft Law of Ukraine 'On Amendments to Certain Laws of Ukraine (on Improving the Establishment and Operation of Arbitration Courts in order to restore confidence in arbitration)', which was adopted in the first reading. This project proposes: to change the procedure for state registration of arbitration courts, to strengthen the requirements for organisations under which permanent arbitration courts may be established; to expand the powers of the Arbitration Chamber of Ukraine, in particular, its powers will include establishing compliance of the founder of the permanent arbitral tribunal with the requirements of the Law and providing a conclusion, and in case of non-compliance by the founder of the permanent arbitration court with the requirements of the Law, the Arbitration Chamber of Ukraine will have to apply to the state registration body with a corresponding application. Thus, as we see, the Cabinet of Ministers proposes stricter mechanisms to control the 'quality' of domestic arbitration courts and, for some reason, proposes to use a more liberal approach to ongoing international commercial arbitration.

This proposal creates a potential opportunity to establish ICAs dependent on financial and industrial groups and other large enterprises with an unclear reputation. Indicative in this respect is the experience of Latvia, which legislation has long contained minimum requirements for the founders of arbitration courts, which can also consider international commercial disputes, and in which there are more than 100 arbitrations. Now, Latvian lawyers comment on this situation as follows

The inability of an arbitral tribunal (which, according to national law, has the right to hear international disputes) to provide the foreign party with confidence in impartiality and independence, as well as in its procedural rights, appointment of highly qualified arbitrators subject to the obligation to include in standard contracts a reference to such 'departmental arbitrations' makes such departmental business 'localised', reduces the inflow of foreign investment into the state, which, declaring the possibility of arbitration, gives it to corporate interests. ${ }^{16}$

The following proposal of the Draft Law would allow international arbitrations to be established at a branch or representative office of an organisation registered in accordance with the legislation of a foreign state on the territory of Ukraine, provided that such organisation is the founder of an arbitration institution abroad, the term of operation of which is five years if it led to the establishment of branches of the most famous and authoritative arbitration institutions in the world in Ukraine, could be supported, but this is unlikely given the following. First, the arbitration regulations of the ICC, LCIA, SIAC, and others provide for the possibility of conducting arbitration in any country by agreement of the parties to the dispute, and arbitration institutions do not need to spend money on the establishment and maintenance of branches for this. Secondly, the establishment of branches implies that it should ensure the consideration of an adequate number of disputes per year, and not one or two (according to statistics in 2019, the Arbitration Institute of the Stockholm Chamber of Commerce considered seven disputes with the participation of Ukraine). Third, the place of arbitration has legal significance, which is that the challenge of the arbitral award will be made to the state courts of the country of the decision and under the laws of that country. Therefore, it is unlikely that the Arbitration Institute of the Stockholm Chamber of

16 'Long Live Baltic Arbitration' (2005) 26 (392) International Arbitration (Pravo.ua) <https://pravo.ua/ articles/da-zdravstvuet-baltijskij-arbitrazh/> accessed 25 July 2021. 
Commerce or the parties to the arbitration agreement that have chosen this arbitration are willing to transfer the procedure for challenging the arbitration decision from the courts of Sweden to the courts of Ukraine.

\section{CHANGING THE PROCEDURE FOR APPOINTING ARBITRATORS}

Proposal to amend Art. 461 of the CPC of Ukraine regarding the right of the appellate court to decide on the appointment, revocation, and termination of powers (mandate) of the arbitrator of permanent arbitration institutions needs significant refinement, as it does not provide criteria for selection of arbitrators, terms, and procedures for appointment, revocation and does not regulate other important procedural issues.

In addition to these comments, it should be noted that the imposition on the court of the power to appoint an arbitrator is not fully in line with recognised international practice. In cases where the appointment of an arbitrator is complicated (a party does not participate in the formation of the arbitration or the mechanism chosen by the parties does not otherwise allow the formation of the arbitration) and the rules of regulation do not allow to find an effective way out of this situation, in particular, by making an appointment by an arbitration institution, the appointment is made by an authorised institution (appointing authority).

\section{CONCLUSIONS}

Any reform of legislation, including arbitration, must be objectively determined by the specific needs of society and aimed at improving the mechanism of legal regulation of relevant public relations. Unfortunately, the purpose of the Draft Law in terms of creating new permanent arbitration courts for non-profit organisations in Ukraine is not due to the growing number of cases and the workload of the ICAC at the CCI of Ukraine, or long deadlines or low-quality arbitration awards in Ukraine, or high rates of revocation of arbitral awards by state courts.

It cannot be said that the adoption of the Draft Law will increase the effectiveness of legal regulation or the quality of the rules governing international commercial arbitration. On the contrary, the proposed changes in legislation may lead to the loss of authority of international commercial arbitration in Ukraine, create problems related to the lack of mechanisms and criteria by which state courts must appoint arbitrators, and so on.

Given the fair criticism of the Draft Law by lawyers, scholars, and arbitrators, the lack of objective preconditions for the adoption of the law in the proposed version is hardly appropriate for its adoption by the Parliament of Ukraine.

\section{REFERENCES}

1. Law of Ukraine 'On International Commercial Arbitration' of 24 February 1994 No $4002-$ XII (updated on 15 December 2017) <http://zakon5.rada. gov.ua/laws/show/4002-12/ parao171\#0171> accessed 16 July 2021.

2. Law of Ukraine 'Civil Procedure Code of Ukraine' of 18 March 2004 No 1618-IV (updated on 4 November 2018) <http://zakon.rada.gov.ua/laws/show/1618-15> accessed 16 July 2021. 
3. Draft Law of Ukraine 'On Amendments to Certain Legislative Acts of Ukraine Concerning the Improvement of Arbitration Activities' of 08 April 2021 No 5347 <http://w1.c1.rada.gov. ua/pls/zweb2/webproc4_1?pf3511=71614> accessed 25 July 2021.

4. Agreement on Promotion and Mutual Protection of Investments between the Government of Ukraine and the Government of the State of Qatar <https://zakon.rada.gov.ua/laws/ show/634_004-18\#Text> accessed 25 July 2021.

5. Nahnybida V,'The Crisis of Trust' (2021) 4 (129) Court Bulletin.

6. Janićijević D, ‘Delocalization in International Commercial Arbitration' (2005) 3 (1) Law and Politics 63.

7. Moss DK, Autonomy of Will in the Practice of International Commercial Arbitration (Moscow 1996) 11.

8. Piątkowska K, 'The Concept of "Denationalization" (or the Equivalent "Delocalization") in the Context of the US Federal Court Decision in Chromalloy Aeroservices Inc v Arab Republic of Egypt 939 F Supp 907 (DDC 1996) and the Amsterdam Court of Appeal Decision in Yukos Capital SARL v OAO Rosneft' (Wrocław 2009).

9. Paulsson J, The Idea of Arbitration (Oxford University Press 2013).

10. Mann FA, 'Lex Facit Arbitrum' in P Sanders (ed), International Arbitration: Liber Amicorum for Martin Domke (The Hague: Martinus Nijhoff 1967) 157-183.

11. United Nations Commission on International Trade Law, UNCITRAL Model Law on International Commercial Arbitration, adopted by UNCITRAL on 21 June 1985 in the wording of 2006 (United Nations Publication 2008) 40.

12. Fouchard P, 'L'autonomie de l'arbitrage commercial international' (1965) 1 Revue de l'arbitrage 99-120.

13. Kravtsov SO, International Commercial Arbitration and National Courts: Monograph (Pravo 2014) 232.

14. Kovalskyi V, 'New Initiatives for Improving the Legislation of Ukraine in the Field of International Arbitration: Pro Et Contra' (2 May 2021, Yurinkom Inter) < https://yurincom.com/legal_practice/ analitychna_yurysprudentsiia/novi-initsiatyvy-shchodo-vdoskonalennia-zakonodavstvaukrainy-u-sferi-mizhnarodnoho-arbitrazhu-pro-et-contra/> accessed 25 July 2021.

15. Podtserkovny O, 'Reform and content' <https://icac.org.ua/wp-content/uploads/StattyaPodtserkovnogo.pdf> accessed 25 July 2021.

16. 'Long Live Baltic Arbitration' (2005) 26 (392) International Arbitration (Pravo.ua) <https:// pravo.ua/articles/da-zdravstvuet-baltijskij-arbitrazh/> accessed 25 July 2021. 